\title{
Karyotype Analysis of Chlorophytum kolhapurense Sardesai, S. P. Gaikwad \& S. R. Yadav: A Rare Endemic from Northern Western Ghats
}

\author{
Manoj Lekhak*, Avinash Asraji Adsul and Shrirang Ramchandra Yadav \\ Department of Botany, Shivaji University, Kolhapur-416 004, Maharashtra, India \\ Received March 8, 2010; accepted March 23, 2010
}

\begin{abstract}
Summary The genus Chlorophytum Ker-Gawl, with about 216 species, is distributed mainly in the Old World tropics especially in Africa and India. In India 17 species represent the genus. This genus has attracted the interest of scientific community owing to the presence of pharmacologically important saponins. Recently described species, C. kolhapurense Sardesai, S. P. Gaikwad \& S. R. Yadav was studied cytologically, the chromosome number was $2 n=16$ and $n=8$ and the karyotype was symmetrical.
\end{abstract}

Key words Chlorophytum kolhapurense, Karyotype, Meiosis, Mitosis.

The genus Chlorophytum Ker-Gawl., is one of the main genera of the family Anthericaceae (Conran 1998). It comprises of about 215 species, distributed in the Old World tropics especially in Africa and India (Mabberley 2000, Govaerts 2006). Recently Malpure and Yadav (2009) added new taxa to the genus viz., C. gothanense Malpure \& S. R. Yadav making a final count of 216. In India, the genus is represented by 17 species (modified after Karthikeyan et al. 1989) of which Western Ghats alone harbors 15 species.

The genus has been studied in detail from cytotaxonomic and cytogeographic points of view by Pahuja and Kumar (1969), Baldwin and Speese (1951), Sheriff (1967, 1971), Sheriff and Cheenaveraiah (1975), Mukherjee (1975), Naik (1977a) and others (Table 1). These studies have revealed that there are 2 basic chromosome numbers in this genus, $x=7, x=8$ and polyploidy has certainly played active role in speciation. However, from the cytological studies of $C$. laxum (Naik 1976), it is evident that these numbers are secondary, mostly probably derived from the hypothetical original base number $x=4$, by interspecific hybridization and subsequent polyploidy. It has also been conclusively shown that $x=7$ has been derived from $x=8$ by deletion (Naik 1977b).

Chlorophytum kolhapurense Sardesai, S. P. Gaikwad \& S. R. Yadav (Figs. 1a-f), is a rare endemic of northern Western Ghats. It grows in sandy soils on granite gneiss rocks in scrub forests in open ground around trees and shrubs with an altitude of about $600 \mathrm{~m}$ from MSL (Sardesai et al. 2006). C. kolhapurense is an unexploited plant of potential economic value. Like other medicinally important members of the same genus such as $C$. arundinaceum and $C$. borivilianum, the fasciculated horizontal roots (Fig. 1e) of C. kolhapurense can serve as a major source of pharmacologically important saponins. In light of above fact the present paper aims studies on chromosome number and karyotype analysis of the species.

\section{Materials and methods}

The materials, fascicled roots of $C$. kolhapurense were collected from the wild resources of northern Western Ghats. The voucher specimens are deposited in the Herbarium of Department of

\footnotetext{
* Corresponding author, e-mail:mlekhak@gmail.com
} 
Table 1. Chlorophytum species and their somatic chromosome counts

\begin{tabular}{|c|c|c|c|}
\hline S. No. & Species & $2 n$ & Authors \\
\hline 1 & Chlorophytum acaule Baker & 16 & Sheriff and Cheenaveeraiah (1972) \\
\hline 2 & *Chlorophytum amaniense Engl. & 14 & Jones and Smith (1967) \\
\hline 3 & Chlorophytum arudinaceum Baker & $28,40,42$ & $\begin{array}{l}\text { Kumar and Pahuja (1967), Malla et al. (1978), } \\
\text { Malla et al. (1979), Pahuja and Kumar (1969), } \\
\text { Zaman and Khatun (1975) }\end{array}$ \\
\hline 4 & Chlorophytum attenuatum Baker & $14,42,84$ & $\begin{array}{l}\text { Boraiah (1967), Sheriff and Cheenaveeraiah } \\
\text { (1975) }\end{array}$ \\
\hline 5 & $\begin{array}{l}\text { Chlorophytum bharuchae Ansari, Raghavan } \\
\text { \& Hemadri }\end{array}$ & 16 & Naik (1974, 1977b, 1979), Raghavan et al. (1977) \\
\hline 6 & $\begin{array}{l}\text { Chlorophytum borivilianum Santapau \& } \\
\text { R. R. Fern. }\end{array}$ & 16 & Raghavan et al. (1977) \\
\hline 7 & *Chlorophytum comosum (Thunb.) Jacques & 28 & Naik (1980) \\
\hline 8 & Chlorophytum glaucoides Blatt. & 42 & Naik (1977b), Raghavan et al. (1977) \\
\hline 9 & Chlorophytum glaucum Dalzell & 16,42 & $\begin{array}{l}\text { Raghavan et al. (1977), Sheriff and } \\
\text { Cheenaveeraiah (1972) }\end{array}$ \\
\hline 10 & $\begin{array}{l}\text { Chlorophytum gothanense Malpure \& } \\
\text { S. R. Yadav }\end{array}$ & 28 & Malpure and Yadav (2009) \\
\hline 11 & Chlorophytum heynei Rottler ex Baker & $14,28,56$ & $\begin{array}{l}\text { Mathew and Thomas (1974), Sheriff and } \\
\text { Cheenaveeraiah (1972), Thomas, K. (1960), } \\
\text { Thomas, S. (1960) }\end{array}$ \\
\hline 12 & Chlorophytum khasianum Hook. f. & $22,56,60$ & Naik (1977b), Sharma and Sarkar $(1967,1968)$ \\
\hline 13 & $\begin{array}{l}\text { Chlorophytum kolhapurense Sardesai, } \\
\text { S. P. Gaikwad \& S. R. Yadav }\end{array}$ & 16 & Present communication \\
\hline 14 & Cholophytum laxum $\mathrm{R} . \mathrm{Br}$. & $14,16,32$ & $\begin{array}{l}\text { Baldwin and Speese (1951), Boraiah (1966), } \\
\text { Mathew and Thomas (1974), Naik (1976), } \\
\text { Raghavan et al. (1977), Sheriff and Nagaraj } \\
\text { (1971), Sheriff and Rao (1974) }\end{array}$ \\
\hline 15 & Chlorophytum malabaricum Baker & 42 & $\begin{array}{l}\text { Jones and Smith (1967), Mathew and Thomas } \\
\text { (1974), Naik (1977b) }\end{array}$ \\
\hline 16 & Cholophytum nepalensis (Lindl.) Baker & $\begin{array}{l}28,42,50 \\
54,56,63\end{array}$ & Basu and Jha (2008) \\
\hline 17 & Chlorophytum nimmonii Dalzell & 42 & Raghavan et al. (1977) \\
\hline 18 & Chlorophytum tuberosum (Roxb.) Baker & 16 & $\begin{array}{l}\text { Dynansagar and Chowta (1969), Kumar and Rao } \\
\text { (1958), Naik (1977b), Pahuja and Kumar (1969), } \\
\text { Raghavan et al. (1977), Sheriff and } \\
\text { Cheenaveeraiah (1972) }\end{array}$ \\
\hline
\end{tabular}

* Denotes species which are used as ornamentals in India.

Botany, Shivaji University, Kolhapur (SUK). For mitotic studies the root tips obtained from tubers were used after pretreatment with aqueous saturated solution of para-dichlorobenzene at $8-10^{\circ} \mathrm{C}$ for 4 to $5 \mathrm{~h}$. Root tips were hydrolyzed in $1 \mathrm{~N} \mathrm{HCl}$ and stained and squashed with $2 \%$ propionic-orcein. Suitable somatic plates were photographed with a Nikon Coolpix 4500 digital camera. Ten wellseparated somatic chromosome plates were selected for karyotype analysis by adopting the method of Levan et al. (1964). For analysis and comparison of the karyotype, the chromosomes of $C$. kolhapurense were categorized on the basis of their length and centromeric position. The degree of karyotype asymmetry has been determined as per the categories of Stebbins (1971).

Meiotic studies were done on the pollen mother cells (PMCs). Flower buds were fixed in Carnoy's fluid (acetic acid:alcohol) $(1: 3)$ during morning hours. Propionic-orcein technique was used for staining the chromosomes. 

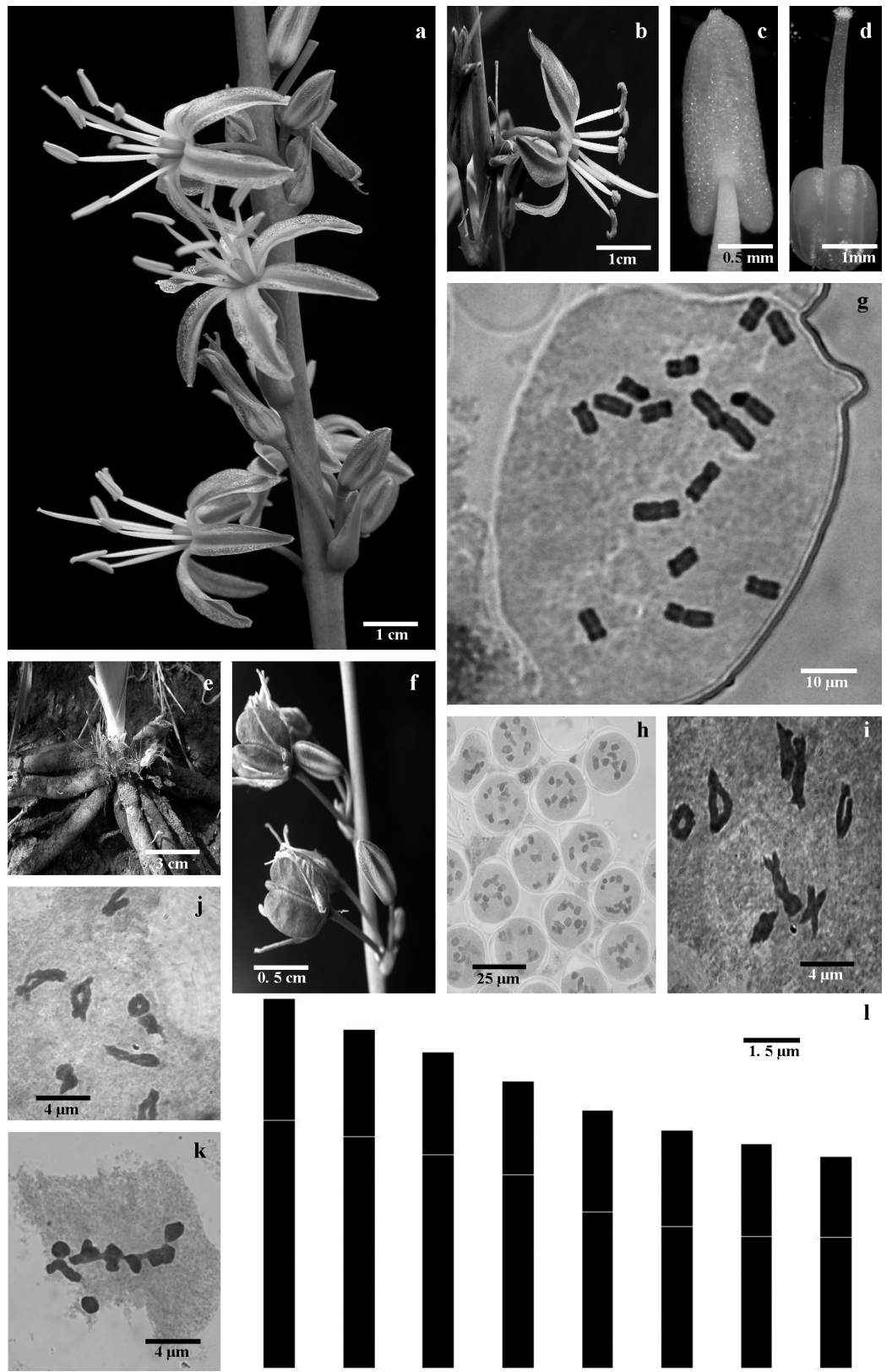

$\overline{1.5 \mu \mathrm{m}}$

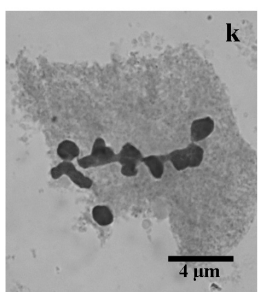

Fig. 1. Chlorophytum kolhapurense Sardesai, S. P. Gaikwad \& S. R. Yadav. (a) inflorescence, (b) flower close-up, (c) stamen, (d) gynoecium, (e) fascicled horizontal roots, (f) capsules, (g) somatic chromosome number $2 n=16$, (h) PMC's showing haploid chromosome number $n=8$, (i) and (j) diakinesis showing 8 bivalents, (k) metaphase-I, (1) idiograph.

\section{Results}

Somatic chromosome number of $C$. kolhapurense is $2 n=16$ (Fig. 1g). Four different types of chromosomes could be identified in the species examined karyologically (Table 3 ). These ranged from $6.18 \mu \mathrm{m}$ to $10.79 \mu \mathrm{m}$ in length and centromere positions varied from submedian to median. Mean chromosome length was found to be $8.19 \mu \mathrm{m}$. The data for karyotypic analysis are presented 
Table 2. Karyotype analysis of C. kolhapurense

\begin{tabular}{ccccccccc}
\hline \hline $\begin{array}{c}\text { Chromosome } \\
\text { pairs }\end{array}$ & $\begin{array}{c}\text { Long arm } \\
(1)(\mu \mathrm{m})\end{array}$ & $\begin{array}{c}\text { Short arm } \\
(\mathrm{s})(\mu \mathrm{m})\end{array}$ & $\begin{array}{c}\text { Total length } \\
\mathrm{c}=1+\mathrm{s}(\mu \mathrm{m})\end{array}$ & $\begin{array}{c}\text { ' } d \text { ' value } \\
1-\mathrm{s}(\mu \mathrm{m})\end{array}$ & $\begin{array}{c}\text { ' } r \text { ' value } \\
1 / \mathrm{s}\end{array}$ & $\begin{array}{c}\text { ' } i \text { ' value } \\
\mathrm{s} / \mathrm{c} \times 100\end{array}$ & $\begin{array}{c}\text { Centromere } \\
\text { position }\end{array}$ & $\begin{array}{c}\text { Type } \\
\text { I }\end{array}$ \\
\hline & $7.25 \pm 1.20$ & $3.54 \pm 0.43$ & $10.79 \pm 1.32$ & 3.71 & 2.05 & 32.78 & $\mathrm{Sm}$ & $\mathrm{A}$ \\
II & $6.76 \pm 0.87$ & $3.15 \pm 0.57$ & $9.90 \pm 0.96$ & 3.61 & 2.15 & 31.76 & $\mathrm{Sm}$ & $\mathrm{B}$ \\
III & $6.24 \pm 0.53$ & $3.00 \pm 0.73$ & $9.24 \pm 0.94$ & 3.23 & 2.08 & 32.51 & $\mathrm{Sm}$ & $\mathrm{B}$ \\
IV & $5.65 \pm 0.99$ & $2.72 \pm 0.32$ & $8.37 \pm 1.00$ & 2.92 & 2.07 & 32.54 & $\mathrm{Sm}$ & $\mathrm{B}$ \\
V & $4.56 \pm 0.52$ & $2.98 \pm 0.61$ & $7.54 \pm 0.88$ & 1.58 & 1.53 & 39.55 & $\mathrm{~m}$ & $\mathrm{C}$ \\
VI & $4.14 \pm 0.37$ & $2.80 \pm 0.43$ & $6.94 \pm 0.59$ & 1.35 & 1.48 & 40.30 & $\mathrm{~m}$ & $\mathrm{C}$ \\
VII & $3.85 \pm 0.51$ & $2.71 \pm 0.29$ & $6.56 \pm 0.65$ & 1.14 & 1.42 & 41.31 & $\mathrm{~m}$ & $\mathrm{C}$ \\
VII & $3.81 \pm 0.43$ & $2.37 \pm 0.38$ & $6.18 \pm 0.48$ & 1.44 & 1.61 & 38.32 & $\mathrm{~m}$ & $\mathrm{D}$ \\
\hline
\end{tabular}

Table 3. Types of chromosomes in C. kolhapurense

\begin{tabular}{|c|c|}
\hline Types of Chromosomes & Description \\
\hline Type A (Chromosome I): & $\begin{array}{l}\text { A pair of long chromosomes }(10.79 \mu \mathrm{m}) \text { with submedian Centromere }(\mathrm{sm}) \text {. } \\
\text { This is the longest pair. }\end{array}$ \\
\hline Type B (Chromosomes II, III and IV): & $\begin{array}{l}3 \text { pairs of long chromosomes }(8.37-9.90 \mu \mathrm{m}) \text { with submedian Centromere } \\
(\mathrm{sm}) \text {. }\end{array}$ \\
\hline Type C (Chromosomes V, VI and VII): & 3 pairs of short chromosomes $(6.56-7.54 \mu \mathrm{m})$ with median Centromere $(\mathrm{m})$. \\
\hline Type D (Chromosomes VIII): & A pair of short chromosomes $(6.18 \mu \mathrm{m})$ with median Centromere $(\mathrm{m})$. \\
\hline
\end{tabular}

in Table 2 and is idiographically represented in Fig. 11.

The karyotype analysis of $C$. kolhapurense can be summarized as follows: Haploid chromosome no.: $n=8$, Diploid chromosome no.: $2 n=16$, Total chromosome length (TCL) $\mu \mathrm{m}$ : 6.18-10.79, Total chromosome length of haploid (TCLH): 65.52, Range of total chromosome length (TCL) \%: 9.43-16.47, Karyotype formula: $2 \mathrm{~A}^{\mathrm{sm}}+6 \mathrm{~B}^{\mathrm{sm}}+6 \mathrm{C}^{\mathrm{m}}+2 \mathrm{D}^{\mathrm{m}}$, Karyotype symmetry: $4 a$.

\section{Discussion}

In India there are 6 species (including $C$. kolhapurense) which have been reported to have $2 n=16$ as their somatic chromosome number (Table 1). After comparing the data on difference between longest and shortest chromosome (L-S), the ratio of longest to shortest chromosome (L/S) and TCLH value (Patil et al. 1987) amongst these species it can be said that $C$. kolhapurense and $C$. tuberosum come near to each other than to any other species.

The karyotype was found to be symmetrical type of 4a as per Stebbins's (1971) classification which seems to be comparatively more advanced to the 2a grade of $C$. tuberosum. Similarly, $C$. attenuatum, $C$. comosum and $C$. laxum exhibit $2 \mathrm{a}$ grade. The other grades common in Chlorophytum species are 2b (C. glaucum and C. orchidastrum $=C$. nimmonii, Patil et al. 1987) and 3b (C. arundinaceum, Pahuja and Kumar 1969). The detailed karyotype analysis of $C$. kolhapurense showed that, out of the 8 pairs of chromosomes 4 pairs have submedian centromere while other 4 pairs possess median centromere. Subterminal chromosomes are relatively more in $C$. nimmoni, C. glaucum, C. glaucoides, C. khasianum, C. nepalense and C. comosum (Patil et al. 1987, Naik 1977a). In case of C. malabaricum and C. tuberosum only 1 pair has subterminal centromere while in C. bharuchae all chromosomes have submedian centromere (Naik 1977b).

Apart from this, as proposed by Naik (1977) species with $x=8$ are adapted to arid or semi-arid conditions, it can be said that $C$. kolhapurense is not an exception to it, which occurs on hilly tracts of some parts of Maharashtra and Karnataka. 
However, Naik (1976), reported following abnormalities in the genus Chlorophytum are: 1) multivalent association, 2) unoriented bivalent at Metaphase I and II and Anaphase I and II, 3) nondisjunction of the entire complement while in case of $C$. tuberosum occasionally unoriented bivalents were observed. Meiosis was found to be normal as PMCs showed (Figs. 1h-k) 8 bivalents with very few anomalies.

\section{Acknowledgements}

Authors are grateful to the Head, Department of Botany, Shivaji University, Kolhapur for providing research facilities. Thanks are due to Mr. Sandeep R. Pai for his constant encouragement during this work. Authors are also thankful to MoEF and DBT, Government of India, New Delhi for financial assistance.

\section{References}

Baldwin, J. T. and Speese, B. M. 1951. Cytogeography of Chlorophytum in Liberia. Am. J. Bot. 38: 153-156.

Basu, S. and Jha, T. B. 2008. Chlorophytum nepalense (Lindl.) Baker-An unexplored plant of potential economic value? Curr. Sci. 95: 439.

Boraiah, G. 1966. A note on cytotaxonomy of Chlorophytum laxum R. Br. Curr. Sci. 35: 314-315.

— 1967. Cytology of Chlorophytum attenuatum and Chlorophytum undulatum. In Wall Mysore J. Agric. Sci. 1: $294-295$.

Conran, J. G. 1998. Anthericaceae. In: K. Kubitzki (Ed.). Families and Genera of Vascular Plants. Vol III. Springer, Berlin.

Dnyansagar, V. R. and Chowta, C. D. 1969. Karyotype of Chlorophytum tuberosum Baker. Proc. 56th Indian. Sci. Congr. Part 3: 391-392.

Govaerts, R. 2006. World check list of Asparagaceae. The Board of trustees of the Royal Botanic Gardens, Kew. Published on the internet; http:// www.kew.org/wcsp/accessed 20 October 2002; 08:30 IST.

Jones, K. and Smith, J. B. 1967. The Chromosomes of Liliaceae: The Karyotype of twenty five tropical species. Kew Bull. 21: 31-38.

Karthikeyan, S., Jain, S. K., Nayar, M. P. and Sanjappa, M. 1989. Florae Indicae Enumeratio: Monocotyledonae. Flora of India Series 4. Botanical Survey of India, Calcutta.

Kumar, L. L. S. and Rao, H. K. S. 1958. Chromosome number in Chlorophytum tuberosum Baker. Curr. Sci. 27: 406-407.

Kumar, V. and Pahuja, A. N. 1967. Karyotype of Chlorophytum arundinaceum Baker, from Bihar. Proc. 54th Indian. Sci. Congr. Part 3: 399.

Levan, A., Fredge, K. and Sandberg, A. 1964. Nomenclature for centromeric positions on chromosomes. Hereditas 52: 201.

Mabberley, D. J. 2000. The Plant Book. Ed. 2. Cambridge University Press, Cambridge.

Malla, S. B., Bhattarai, S., Saiju, H. and Kayastha, M. 1978. In IOPB chromosome number reports LXII. Taxon 27: $519-535$.

- - - - - and - 1979. In IOPB chromosome number reports LXV. Taxon 28: 627-637.

Malpure, N. V. and Yadav, S. R. 2009. Chlorophytum gothanense, a new species of Anthericaceae from Western Ghats of India. Kew Bull. 64: 739-741.

Mathew, P. M. and Thomas, K. J. 1974. Cytological studies on Chlorophytum. New Bot. 1: 34-45.

Mukherjee, N. 1975. Phytogeography and phylogeny of Chlorophytum Ker-Gawl. (Liliaceae). Bull. Bot. Soc. Bengal 29: 75-82.

Naik, V. N. 1974. Cytological studies in Chlorophytum bharuchae Ansari, Raghavan et Hemadri. Curr. Sci. 43 : 161.

- 1976. Chromosomal behavior and evolutionary trend in Chlorophytum. Bot. J. Linn. Soc. 72: 45-50.

- 1977a. Cytotaxonomic studies of six Indian species of Chlorophytum. Bot. J. Linn. Soc. 74: 297-308.

- 1977b. Erroneous report of the new basic chromosome number in Chlorophytum. Sci. Cult. 43: 260-261.

- 1979. Chromosomal behavior in Chlorophytum bharuchae Ansari, Raghavan et Hem. Indian. J. Bot. 2: 59-62.

- 1980. Chlorophytum (Liliaceae) in Indian gardens. J. Ind. Bot. Soc. 59: 67-71.

Pahuja, A. N. and Kumar, V. 1969. Cytogeography of three species of Chlorophytum. Curr. Sci. 38: 469-471.

Patil, V. P., Kumbhojkar, M. S. and Gandhi, S. S. 1987. Karyomorphological studies in Chlorophytum Ker-Gawl. Cytologia 52: 543-550.

Raghavan, R. S., Ansari, M. Y. and Kamble, Y. S. 1977. Cytotaxonomic studies in Chlorophytum Ker-Gawl. Curr. Sci. 46: 534-535.

Sardesai, M. M., Gaikwad, S. P. and Yadav, S. R. 2006. A New species of Chlorophytum (Anthericaceae) from Western Ghats, India. Kew Bull. 61: 269-271. 
Sheriff, A. 1967. Cytological and cytotaxonomic studies in certain members of Liliaceae. Ph. D. Thesis, Bangalore University.

— 1971. Karyomorpholoical studies in four hexaploid species of Chlorophytum. J. Cytol. Genet. Congr. Suppl.: 26-32.

— and Chennaveeraiah, M. S. 1972. Karyomorphology of four diploid species of Chlorophytum. Nucleus 15: 39-45.

— and - 1975. Cytological studies in Chlorophytum attenuatum complex and cytotaxonomic considerations. Cytologia 40: $401-408$.

— and Nagaraj, M. 1971. Cytogeography of Chlorophytum laxum. Proc. 58th Indian Sci. Congr. Part 3: 466

— and Rao, U. G. 1974. Asynapsis in Chlorophytum laxum. Curr. Sci. 43: 291-293.

Sharma, A. and Sarkar, A. K. (Ed.) 1967-1968. Chromosome number reports of plants. In Annu. Report, Cytogenet. Lab., Dept Bot., Univ. Calcutta, Res. Bull. 2: 38-48.

Stebbins, G. L. 1971. Chromosomal Evolution in Higher Plants. Edward Arnold, London.

Thomas, K. J. 1960. Cytogenetic investigation on the genus Chlorophytum. II. Reciprocal translocation in somatic chromosome of Chlorophytum heynei Baker. Cytologia 25: 97-100.

Thomas, S. 1960. Chromosome aberrations and Mutation in nature. Curr. Sci. 29: 376-379.

Zaman, M. A. and Khatun, F. A. 1975. A new basic chromosome number in genus Chlorophytum. Cytologia 40: 491-496. 